\title{
Pengaruh Pendapatan Bank Umum Syariah terhadap Risiko Operasional Periode 2015-2018 di Indonesia
}

\author{
Aisya Farina \\ Universitas Islam Negeri Sunan Kalijaga,Indonesia. E-mail:ichafarina@gmail.com
}

\section{ARTICLE INFO}

Kata Kunci:
Ekonomi Islam; Koperas
Syariah 212
Fee; Ijarah,
Mudharabah;
Murabahah;
Musyarakah, Risiko
operasional.

Cara Sitasi:
Farina, Aisya.
"Pengaruh
Pendapatan Bank
Umum Syariah
terhadap Risiko
Operasional Periode
2015-2018 di
Indonesia." At-
Taradhi: Jurnal Studi
Ekonomi 11, no. 1
(2020): 67-85.

\begin{abstract}
Every effort is made by Islamic banks in profit or benefits from the revenues cannot be separated from risk. One of them is the operational risk as to the risk resulting from the inadequacy and/or failed internal processes, human error, system failure, and/or the presence of external events affecting the operations of the bank. This study was conducted to determine the level of income that Islamic banks murabaha, Ijarah, Mudharabah, Musharaka and fees against operational risks in Islamic banks with the period 2015 through 2018. The sample used is 11 Islamic Banks (BUS) using purposive sampling method. Data analysis techniques were used that panel data regression analysis with a significance level of 5\% with statistical tools such as Eviews. The calculation for operational risk ATMR views of operational risk using the method of calculation of Basel II Basic Indicator Approach (PID). Income as independent variables, murabaha, Ijarah, Mudharabah, Musharaka, and fees. Of the independent variables that affect the murabaha, Musharaka, and fees while no effect Ijarah and Mudharabah.
\end{abstract}

Penelitian ini dilakukan untuk mengetahui tingkat pendapatan bank umum syariah terhadap risiko operasional bank umum syariah periode 2015 sampai dengan 2018. Sampel yang digunakan 11 Bank Umum Syariah (BUS) menggunakan metode purposive sampling. Metode analisis yang digunakan yaitu analisis regresi data panel dengan program Eviews. Perhitungan untuk risiko operasional dilihat dari ATMR risiko operasional menggunakan perhitungan Basel II yaitu metode Pendekatan Indikator Dasar (PID). Variabel dependen dalam penelitian ini yaitu risiko operasional. Risiko operasional sebagai risiko akibat ketidakcukupan dan/atau tidak berfungsinya proses internal, kesalahan manusia, kegagalan sistem, dan/atau adanya kejadian-kejadian eksternal yang mempengaruhi operasional bank. Pendapatan sebagai variabel independen yaitu murabahah, ijarah, mudharabah, musyarakah, dan fee. Hasil dari variabel independen tersebut yang berpengaruh yaitu murabahah, musyarakah, dan fee sedangkan yang tidak berpengaruh ijarah dan mudharabah.

\section{Pendahuluan}

Pengelolaan sistem keuangan yang ada di dunia ini semakin meningkat mengikuti perubahan-perubahan yang terjadi. Sistem keuangan merupakan bentuk yang mengatur pengelolaan keuangan. Rose mengemukakan bahwa yang dimaksud dengan sistem keuangan adalah sekelompok lembaga, pasar, perundang-undangan, aturan-aturan serta 
bagaimana surat berharga dapat diperjual belikan, mengacu pada tingkat suku bunga, serta pelayanan jasa keuangan yang didapatkan kemudian ditawarkan kepada semua titik Negara yang ada di dunia. Dengan adanya sistem keuangan ini terbentuklah berbagai macam lembaga keuangan untuk mengelola keuangan tersebut. Lembaga keuangan terdiri dari keuangan bank, dan bukan bank. ${ }^{1}$ Bank syariah adalah industri yang berbasis hukum Islam berupa larangan akan riba, gharar, spekulasi dan usaha yang berhubungan dengan sektor dosa seperti alkohol atau perjudian. ${ }^{2}$ Bank syariah sampai sekarang ini terus berkembang dan mengalami peningkatan serta banyak kemajuan yang diraih. Otoritas Jasa Keuangan (OJK) telah mempublikasikan data tahun 2015 hingga 2018 menunjukan Bank Umm Syariah (BUS) telah mencapai 14 buah, Unit Usaha Syariah (UUS) berjumlah 20 buah, BPRS berjumlah sebanyak 167 buah, dan total aset BUS sebesar 316, 691 triliun yang dapat dilihat dari tabel 1.

Tabel 1. Pertumbuhan Bank Umum Syariah Periode 2015-2018

(dalam Triliun)

\begin{tabular}{ccccc}
\hline Tahun & Total Aset & Jumlah & Jumlah & Jumlah \\
\hline 2015 & & BUS & UUS & BPRS \\
\hline 2016 & 213,423 & 12 & 22 & 163 \\
\hline 2017 & 284,184 & 13 & 21 & 166 \\
\hline 2018 & 316,691 & 13 & 21 & 167 \\
\hline
\end{tabular}

Sumber Statistik Perbankan Syariah, OJK 2019 (data diolah)

Untuk pertumbuhan bank syariah yang baik juga harus memperhatikan sumber pendapatan yang diperoleh dari bank tersebut. Pada bank syariah terdiri dari berbagai macam sumber pendapatan. Jenis sumber pendapatan bank syariah dari pembiayaan terdiri dari istishna, salam, murabahah, ijarah, mudharabah, dan musyarakah sedangkan sumber pendapatan bank syariah darijasa atau fee terdiri dari ujroh, kbiwalah, kafalah, qard. Semua jenis pendapatan dari pembiayaan dan jasa tersebut yang menjadi dijadikan variabel dalam penelitian ini hanya 5 yakni murabahah, ijarah, mudharabah, musyarakah, dan fee. Berikut ini adalah grafik rata-rata tingkat pendapatan Bank Umum Syariah (BUS) terkait dengan ke 5 variabel yang digunakan dalam penelitian ini yang diperoleh dari statistik perbankan syariah yang terdapat di halaman OJK yaitu dapat dilihat di gambar sebagai berikut:

\footnotetext{
${ }^{1}$ Dwi Agung Prasetyo dan Ni Putu Ayu Darmayanti, Pengaruh Risiko Kredit, Likuiditas, Kecukupan Modal, dan Efisiensi Operasional Terhadap Profitabilitas pada PT. BPD Bali Jurnal Manajemen Universitas Udayana, Vol. 4, No. 9, 2015. 2591.

2 Hayat M. Awan and Khuram Shahzad Bukhari, "Customer's Criteria for Selecting an Islamic Bank: Evidence from Pakistan,” Journal of Islamic Marketing, 2011.
} 


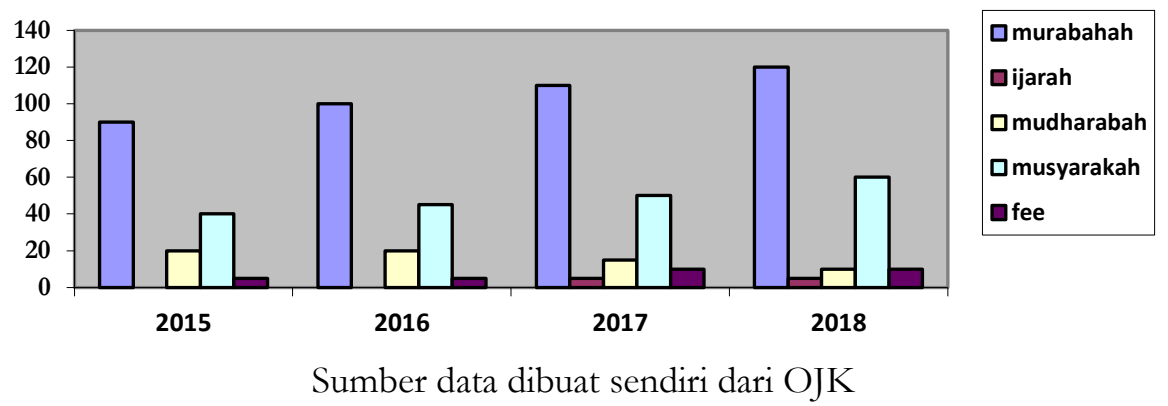

Bank syariah memiliki produk operasional diantaranya produk pendanaan, produk pembiayaan dan produk jasa yang dijalankan sesuai syariah, dimana setiap produk tersebut tidak terlepas dari risiko. Menurut Harland et al, risiko adalah sesuatu yang mengacu pada peristiwa yang tidak pasti, peluang berbahaya, kehilangan, kerusakan atau konsekuensi yang tidak diinginkan. ${ }^{3}$ Perbankan syariah akan selalu dihadapkan dengan bermacam-macam risiko yang kompleks berhubungan dengan aktivitas usaha yang dijalankannya. Risiko terkait perbankan adalah fenomena berupa potensi peristiwa yang terukur (anticipated) atau tidak dapat diukur (unanticipated) sehingga berakibat buruk pada pendapatan serta permodalan bank. Bank umum mempunyai kewajiban menyediakan modal minimumagar ketika tedapat risiko tidak kesulitan dalam menangulanginya terlebih jika risiko itu tinggi yang memerlukan modal besar, sehingga jikalau kecukupan modal telah mencapai batas KPMM bank tidak keepotan dalam menghadapinya. Kewajiban bank umum tersebut tercantum diatur menurut peraturan dari Bank Indonesia No 15/12/PBI/2013 tentang Kewajiban Penyediaan Modal Minimun aBank Umum yang menurut pasal 2 ayat 1 menyatakan suatu keharusan bank memiliki modal hingga 8\% terhadap Aset Tertimbang Menurut Risiko (ATMR). Disamping itu kewajiban akan modal ini juga akan menambah pendapatan modal untuk para pemilik sehingga bank bisa mengembangkan operasi serta memperbanyak deposan. ${ }^{4}$ Sebagai salah satu dari tiga jenis risiko utama yang ada di bankbank komersial yaitu risiko operasional yang telah dimasukkan dalam kerangka manajemen risiko di Basel II Accord untuk meningkatkan stabilitas operasi bank umum. ${ }^{5}$ Menurut Ferreira risiko operasional sebagai suatu risiko yang berasal dari faktor-faktor seperti kegagalan sistem informasi, sistem operasi maupun mekanisme kontrol internal dan eksternal.

Sumber pendapatan bank dengan risiko terbesar berada pada produk pembiayaan. Terkait mengenai pendapatan yang diperoleh BUS selama 4 tahun terakhir dari 2015 hingga 2018 yang terdapat pada gambar 1 dapat dilihat dari lima sumber akad pembiayaan tersebut diatas tidak terlepas dari Non PerformingFinancing (NPF) yakni pembiayaan bermasalah pada akad-akad yang ada pada11 BUS diantaranya yaitu dapat diihat dalam tabel dibawah ini:

\footnotetext{
${ }^{3}$ Rachel Barbosa Santos dan Ualison Rebula de Oliveira, Analysis of Occupational Risk Management Tools for the Firm and Television Industry Jurnal Internasional Ekonomi Industri 72, 2019. 200.

4 Sparta, Analisis Pengaruh Efisiensi dan Kecukupan Modal Terhadap Kinerja Keuangan pada Bank Pembangunan Daerah di Indonesia Jurnal Ekonomi dan Bisnis STIE Indonesia Banking School, Vol. 20, No. 1, 2017. 85 .

${ }^{5}$ Chi Xu, Double Correlation Model for Operational Risk : Evidence from Chinese Commercial Bank Jurnal Universitas Ilmu Pengetahuan dan Teknologi, 10 Oktober 2018. 1.
} 
Tabel 2. Non Performing Financing (NPF) pada Bank Umum Syariah Periode 2015-2018

\begin{tabular}{lcccc}
\hline \multicolumn{1}{c}{ Nama Bank } & \multicolumn{3}{c}{ Tahun } \\
\hline BNI SYH & $\mathbf{2 0 1 5}$ & $\mathbf{2 0 1 6}$ & $\mathbf{2 0 1 7}$ & $\mathbf{2 0 1 8}$ \\
\hline BRI SYH & $2.53 \%$ & $2.94 \%$ & $2.89 \%$ & $2.93 \%$ \\
\hline BCA SYH & $4.86 \%$ & $4.57 \%$ & $6.43 \%$ & $6.73 \%$ \\
\hline PANIN SYH & $0.50 \%$ & $0.70 \%$ & $1.41 \%$ & $1.49 \%$ \\
\hline MEGA SYH & $2.63 \%$ & $2.26 \%$ & $12.52 \%$ & $4.81 \%$ \\
\hline BSM & $4.26 \%$ & $3.30 \%$ & $2.95 \%$ & $2.15 \%$ \\
\hline VICTORIA SYH & $6.06 \%$ & $4.92 \%$ & $4.53 \%$ & $3.28 \%$ \\
\hline BMI & $9.80 \%$ & $7.21 \%$ & $4.59 \%$ & $3.99 \%$ \\
\hline MAYBANK SYH & $7.11 \%$ & $3.83 \%$ & $4.43 \%$ & $3.87 \%$ \\
\hline BUKOPIN SYH & $35.15 \%$ & $43.99 \%$ & $0.00 \%$ & $0.00 \%$ \\
\hline BJB SYH & $2.99 \%$ & $3.17 \%$ & $7.85 \%$ & $5.71 \%$ \\
\hline
\end{tabular}

Non Performing Financing atau pembiayaan bermasalah yang terjadi berbeda-beda dari setiap 11 bank umum syariah syariah. Hal ini pun bisa terjadi dikarenakan beberapa faktor seperti dalam penelitian Asnaini ${ }^{6}$ menyatakan bahwa dari hasil penelitiannya faktor yang bepengaruh positif terhadap NPF yaitu Sertifikat Bank Indonesia Syariah (SBIS) dan Capital Adequacy Ratio (CAR). NPF ini juga bisa mempengaruhi pendapatan BUSsehingga agar dapat terus bisa menjalankan kegiatan usahanya walau sedang menghadapi pembiayaan bermasalah maka BUS memerlukan yang namanya modal. Modal tidak hanya diperlukan oleh BUS saja namun untuk smeua jenis usaha lainnya baik itu bank maupun non bank. Modal bisa didapatkan dari bermacam-macam cara diantaranya melalui kegiatan usaha oleh Bank Umum Syariah yang beroperasi melalui pembiayaan dan jasa untuk mendapatkan modal yang kemudian modal tersebut diputar kembali untuk menjalankan usahanya. Tetapi pendapatan yang didapat oleh bank syariah dari hasil usaha pembiayaan dan jasa yang dilakukannya apakah memiliki pengaruh terhadap risiko operasional. Mengacu pada penjelasan tersebut yang dimaksud risiko operasional yaitu risiko yang amat penting untuk mengukur kecukupan modal dari pendapatan bank syariah yang telah disesuaikan dengan standar minimum modal yang harus dimiliki bank untuk menjaga apabila terjadinya kerugian, memberikan perlindungan terhadap depositor, serta menaikkan standar dan efisiensi sistem keuangan. Hal ini penting karena apabila bank syariah tidak dapat memenuhi standar pendapatan modal minimum sesuai ketetapan yang dibuat Bank Indonesia akan berdampak pada kurangnya modal bank syariah untuk memutar kembali usaha pembiayaan dan jasa yang dilakukannya.

\footnotetext{
${ }^{6}$ Sri Wahyuni Asnaini, "Faktor-Faktor Yang Mempengaruhi Non Performing Financing (NPF) Pada Bank Umum Syariah Di Indonesia," Jurnal Tekun 5, no. 02 (2014): 264-284.
} 
Penelitian mengenai risiko perbankan sudah pernah dilakukan oleh beberapa peneliti. Hasil penelitian oleh Williams ${ }^{7}$ mengenai risiko pendapatan tanpa menggunakan bunga pada bank-bank di Australia menunjukkan bahwa bank-bank yang menjalankan usahanya tanpa bunga mendapatkan pendapatan yang lebih rendah dan berisiko lebih besar dibanding usaha yang memperoleh bunga. Penelitian Williams ini ternyata berkesinambungan terhadap penelitian sebelumnya yang dilakukan Fichez ${ }^{8}$ tentang sumber-sumber serta analisis risiko empiris yang terdapat di bank-bank Eropa, hasil penelitiannya mengemukakan jika pendapatan tanpa bunga menimbulkan risiko dengan jumlah yang cukup besar sedangkan bank yang menggunakan bunga risikonya lebih sedikit. Penelitian lain oleh Abedifar et, aP tentang non interest income and risk lending menunjukkan bahwakegiatan pinjaman tanpa bunga tidak mengalami dampak yang buruk terkait dengan risiko pembiayaan bank.

Dari beberapa penelitian terdahulu mengenai risiko perbankan masih terdapat ketidak konsistenan yang dihasilkan dari beberapa hasil penelitian. Hal tersebut menimbulkan research gap. Berdasarkan latar belakang dan research gap pada penelitian terdahulu yang telah dipaparkan diatas. Penulis tertarik ingin melakukan penelitian lebih lanjut mengenai "Pengaruh Pendapatan Bank Umum Syariah Terhadap Risiko Operasional Periode 20152018 di Indonesia”.

\section{Tinjauan Pustaka}

\section{Teori Kecukupan Modal}

Modal adalah dana para pemilik perusahaan yang diberikan pada akhir tahun buku setelah dihitung keuntungan pada tahun tersebut. Pemilik modal akan memperoleh deviden yaitu keuntunganhasil usaha. Modal bisa dimanfaatkan membeli gedung, tanah, perlengkapan dan jugauntuk hal-halproduktif seperti disalurkan untuk pembiayaan yang berasal dari modal, hasilnya untuk pemilik modal. Tingginya jumlah modal yang disalurkan akan menjadikan nasabah lebih yakin dalam menempatkan depositnya di bank. Bank yang memiliki deposit yang semakin banyak, maka semakin banyak pula yang dikelola untuk menghasilkan profitabilitas. Adapun bank syariah memperoleh dana diantaranya dari modal inti (core capital), titipan (wadiah), wadiah yad al-Amanah, wadiah yad adh-Dhamanah.

De Bondt dan Prast menyatakan bahwa kecukupan modal bank bisa meningkatkan kepercayaan pemegang saham dan deposan serta dapat mengembangkan modal bank sehingga menciptakan global. Bank diperintahkan untuk dapat mengatur likuiditas asetnya agar dapat mencukupi cadangan modalnya agar tidak sampai mengeluarkan biaya yang mahal. $^{10}$

\footnotetext{
7 David Williams-Young, Franco Egidi, and Xiaosong Li, "Relativistic Two-Component Particle-Particle Tamm-Dancoff Approximation," Journal of Chemical Theory and Computation 12, no. 11 (2016): 5379-5384.

${ }^{8}$ R. Fichez et al., "Origine, Transport et Devenir Des Apports Naturels et Anthropiques Dans Le Lagon SudOuest de Nouvelle-Calédonie,” Journal de La Société Des Océanistes, no. 126-127 (2008): 41-58.

9 Pejman Abedifar, Philip Molyneux, and Amine Tarazi, "Non-Interest Income and Bank Lending," Journal of Banking \& Finance 87 (2018): 411-426.

10 Farah Margaretha and Diana Setiyaningrum, "Pengaruh Resiko, Kualitas Manajemen, Ukuran Dan Likuiditas Bank Terhadap Capital Adequacy Ratio Bank-Bank Yang Terdaftar Di Bursa Efek Indonesia," Jurnal Akuntansi Dan Keuangan 13, no. 1 (2011): 47-56.
} 


\section{Risiko}

Risiko bisa diartikan akan adanya peristiwa buruk yang akan terjadi terkait dengan kehidupan, properti maupun deviden dari usaha yang dijalankan. Risiko umumnya berhubungan dengan kemungkinan terjadinya peristiwa diluar yang diharapkan. Bank dalam pengambilan risiko berkaitan dengan kepentingan kinerja bank tersebut tetapi hal ini juga dapat merugikan bank dan stabilitas sistem keuangan nasional buruk jika ini berdampak pada krisis keuangan. Nowicki mengemukakan bahwa elemen penting dalam meminimalisir risiko yang berdampak pada kualitas produk dan / atau jasa, lingkungan, kesehatan pekerja, infrastruktur, dan informasi dilakukan dengan mengidentifikasi dan penilaian terhadap risiko seberapa besar risiko tersebut. Proses identifikasi serta penilaian pada risiko dilakukan dengan menggunakan manajemen risiko.

Manajemen risiko yaitu rangkaian metodologi dan proses semua kegiatan usaha bank didalam mengidentifikasi, pengukuran, pemantauan, dan mengendalian risiko dari. Berdasarkan Peraturan dari Bank Indonesia No 13/23/PBI/2011 mengenai Penerapan Manajemen Risiko bagi Bank Umum Syariah dan Unit Usaha Syariah, menurut pasal 2 dijelaskan bahwa untuk bank secara individual atau bank konsolidasi bersama perusahaan anak, diharuskan melaksanakan manajemen risiko yang efektif. Manajemen risiko di suatu institusi hendaknya menjadi budaya, dimana proses dan sistem mengukur, mengidentifikasi, memantau, dan mengendalikan risiko harus dilakukan secara efektif, terpercaya mampu dan tangguh terinternalisasi dalam setiap bagian atau departemen yang ada pada lembaga keuangan.

\section{Risiko Operasional}

Risiko operasional yaitu risiko akibat proses internal bank kurang berfungsi, human error, kesalahan sistem teknologi atau karena adanya masalah eksternal yang mempengaruhi. ${ }^{11}$ Menurut Trimorita ${ }^{12}$ risiko operasional juga merupakan akibat dari adanya ketidakcukupan dan atau tidak berfungsinya proses internal, kesalahan manusia, kagagalan sistem atau adanya problem eksternal yang mempengaruhi operasional bank. Risiko operasional melekat pada setiap aktivitas fungsional bank seperti kegiatan perkreditan, treasury dan investasi, operasional dan jasa, pembiayaan perdagangan, pendanaan dan instrument utang, teknologi sistem informasi dan sistem informasi manajemen serta pengelolaan sumber daya manusia.

Dalam pengukuran risiko operasional, penelitian ini menggunakan metode Basic Indicator Approach (BIA) dalam mengukur kecukupan modal bank syariah terhadap risiko operasional. Metode BIA digunakan untuk mengukur risiko operasional. Di Uni Eropa dikodifikasi melalui arahan perbankan pada 2013/36/EU dan dimasukkan dalam hukum nasional dengan dekrit No. 157/2014 pada tanggal 24 Oktober bahwa model BIA adalah pendekatan indikator dasar yang paling sederhanauntukmengetahui risiko operasional ketika menghitung kebutuhan modal. Metode BIA ini juga dapat digunakan bank yang menerapkan sistem manajemen risiko dan tidak berskala Internasional. Perhitungan motode ini dikalikan dengan alfa $15 \%$ dan rata-rata pendapatan kotor terhitung dari tiga tahun terakhir. Perhitungan metode ini juga sesuai dengan Surat Edaran Otoritas Jasa

11 Ni Wayan Wita Capriani and I. Made Dana, "Pengaruh Risiko Kredit Risiko Operasional Dan Risiko Likuiditas Terhadap Profitabilitas BPR Di Kota Denpasar," E-Jurnal Manajemen Universitas Udayana 5, no. 3 (2016).

12 Rahmani Timorita Yulianti, "Manajemen Risiko Perbankan Syari'ah," Jurnal Fakultas Hukum UII 3, no. 2 (2009): 151-165. 
Keuangan Nomor 24/SEOJK.03/2016 tentang Aset Tertimbang Menurut Risiko (ATMR), Pendekatan Indikator Dasar untuk pengukuran risiko operasional dihitung menggunakan rata-rata pendapatan bruto (gross income) pertahun (bulan Januari hingga bulan Desember) dari 3 tahun terakhir kemudian dikali dengan alpha sebesar 15\% dengan persamaan:

$$
\frac{\left[\sum(\mathrm{x} \alpha)\right]}{n}
$$

\section{Pendapatan Bank Syariah}

Bank syariah salah satu lembaga keuangan yang memfasilitasi mekanisme ekonomi pada sektor riil melalui kegiatan usaha seperti investasi, pembelian, sewa atau lainnya menurut prinsip-prinsip agama Islam. Prinsip agama Islam memerintahkan dengan adanya perjanjian berdasar hukum Islam antara bank dengan pihak lain dalam menyimpan dana dan atau pembiayaan kegiatan usaha maupun kegiatan lainnya sesuai dengan nilai-nilai Islam menurut Otoritas Jasa Keuangan. ${ }^{13}$

Pendapatan bank syariah ada 4 (empat) sumber diantaranya yaitu:

a. Margin keuntungan berdasarkan akad jual beli

Produk penyaluran dana berdasarkan prinsip jual beli dalam transaksinya dibedakan menurut pembayaran dan waktu penyerahan barang, salah satunya yaitu murabahah adalah akad kerjasama menggunakan prinsip jual beli berdasarkan penjualan dengan tambahan keuntungan (margin) tertentu ditambahkan atas biaya perolehan antara bank dan nasabah. Murrabahah adalah akad kerjasama dalam bentuk jual beli berdasarkan kredit. Pada akad jual beli murabahah atau mark up perbankan mendanai pembelian barang atau aset yang diperlukan nasabahnya dnegan membeli barang itu dari pemasok barang dan kemudian menjualnya kepada nasabah tersebut dnegan menambahkan suatu mark up atau keuntungan. ${ }^{14}$ Segala kegiatan usaha kebanyakan mengandung risiko dan return. Dampak dari Risiko diakibatkan karena terdapat ketidakpastian yang biasa terjadi ketika pengambilan keputusan tidak mempunyai maupun hanya mempunyai sedikit informasi tentang apa yang akan diputuskan di masa depan. Begitu juga pada produk murabahah yang masih terdapat ketidakpastian dalam barang yang diperjualbelikan.

b. Pendapatan sewa berdasarkan akad ijarah

Ijarah merupakan pemindahan hak guna (manfaat) atas suatubarang dan jasa dalam kurun waktu tertentu melalui pembayaran upah/sewa tanpa diikuti dengan pemindahan kepemilikan barang tersebut atau sering dikenal dengan penjualan manfaat. Risiko operasional yang dihadapi bank syariah dalam akad ijarah yaitu ketika berlangsungnya transaksi oleh bank syariah membeliaktiva nasabah dimana aktiva tersebut buruk atau jelek maka dalam hal ini bank syariah harus benar-benar berhati-hati untuk menghindari risiko ini, karena dapat mengurangi kepercayaan nasabah yang mengakibatkan pembatalan kontrak ditengah periode, risiko yang kedua yaitu bank syariah kurang teliti dalam melakukan pemeriksaan karena aktiva dalam sengketa sehingga terjadi penipuan dan kecolongan, risiko yang ketiga yaitu barang tersebut rusak pada saat dalam penguasaan bank syariah yang bisa disebabkan karena besi/alumunium, salah dalam

${ }_{13}$ Nurul Yunita and Muhamad Syaichu, "Analisis Pengaruh Bank Income Structure Terhadap Risiko Bank Syariah Di Indonesia (Studi Kasus Pada Bank Umum Syariah Yang Terdaftar Di Bursa Efef Indonesia Periode 2011-2015)," Diponegoro Journal of Management 6, no. 4 (2017): 714-728.

14 Sutan Remy Sjahdeini, Perbankan Islam dan kedudukannya dalam tata bukum perbankan Indonesia (Jakarta: Pustaka Utama Grafiti, 2005), 64. 
pemakaian, karena kesengajaan oknum tertentu, bisa juga karena kebakaran, maupun kebangkrutan sehingga dalam hal ini bank syariah yang menanggung biaya pemeliharaan aset.

c. Pendapatan berdasarkan Pembiayaan bagi hasil (Mudharabah dan musyarakah)

Mudharabah adalah akad dilakukan dua pihak atau lebih, bertujuanmendapatkan keuntungan, satu pihak sebagai pemilik modal (shabibulmaal) dan mempercayakan modalnya untuk dikelola oleh pihak keduasebaigai pelaksana usaha (mudharib). ${ }^{15}$ Beberapa ketentuan akad mudharabah yaitu pertama, kepada nasabah selaku pengelola modal harus diserahkan jumlah modal secara tunai, baik berupa uang ataupun barang. Namun uang boleh diserahkan secara bertahap dengan ketentuan harus jelas tahapannya dan disepakati bersama. Kedua, pengelolaan modal proyek mudharabab hasilnya diperhitungkan dengan dua cara yaitu hasil usaha dibagi sesuai dengan kesepakatan dalam akad sesuai waktu yang telah disepakati missal setiap bulan. Bank selaku pemilik modal menanggung seluruh kerugian kecuali kerugian akibat nasabah seperti penyelewengan, kecurangan dan penyalahgunaan dana. Risiko pembiayaan mudharabah merupakan risiko operasional sebab prosedur operasional pada transaksi pembiayaan mudharabah yaitu, bank syariah harus memastikan bahwa dengan adanya prosedur tersebut mrnjadikan nasabah benar-benar membeli aset yang telah disediakan.

Musyarakah adalah akad kerjasama untuk usaha tertentu antara dua pihak atau lebih, dan para pihak memberikan kontribusi dana (amal/expertise) dan bersepakat bahwa keuntungan dan risiko akan ditanggung bersama. ${ }^{16}$ Kemampuan dalam memperkirakan risiko atau keuntungan yang mungkin terjadi dalam suatu kerjasama berdasarkan PLS sangat diperlukan karena risiko memiliki dampak negatif bagi usaha yang bisa membuat nilai keuntungan berkurang jika risiko besar. Berdasarkan pembiayaan musyarakah risiko operasional terjadi ketika pihak bank syariah tidak mampu melihat kinerja finansial sehingga tidak cukup memadai dalam memantau proyek yang sedang berlangsung. Oleh karena itu, pihak bank harus menerima informasi keuangan tepat waktu dan yang memadai agar bank syariah dapat mengukur pada waktu yang tepat kemungkinan untuk memperbaiki manajemen.

d. Prinsip jasa/upah berdasarkan akad fee

Upah atau Jasa bank tidak terlepas dari tugas dan fungsi bank sebagai lembaga intermediasi yaitu lem baga yang meperlancar transaksi perdagangan, peredaran uang, dan sebagai lembaga yang memberi jaminan pada nasabah. Jika jasa-jasa bank semakin lengkap maka semakin baik pula jasa diberikan oleh bank tersebut, maka bila nasabah melakukan suatu transaksi cukup di satu bank saja. Jenis jasa yang diberikan bank terkait dengan kemampuan bank segi modal, kelengkapan fasilitas, SDM, jenis bank, dan status bank. Fee based adalah keuntungan dari transaksi jasa bank. walaupun kecil perolehan keuntungan dari jasa bank tetapi mengandung suatu kepastian, hal ini dikarenakan risiko terhadap jasa-jasa bank yang lebih kecil jika dibandingkan pembiayaan. Risiko pendapatan berdasarkan akad jasa/fee berupa imbalan maupun upah dalam risiko operasional yaitu disebabkan oleh buman error atau fraud dan ketidakandalan manajemen teknologi informasi.

15 Adiwarman Karim, Bank Islam Analisis Fiqh dan Keuangan, (Jakarta : PT. Raja Grafindo Persada, 2004). 204205.

${ }^{16}$ Muhammad Rifqi Hidayat dan Parman Komarudin. "Penanganan Non-Performing Finance dalam Akad Musyarakah di Bank Kalsel Syariah." At-Taradhi: Jurnal Studi Ekonomi 9, no. 1 (2018): 2. 


\section{Metode Penelitian}

Jenis penelitian ini merupakan penelitian eksplanatori dengan pendekatan kualitatif. Sumber data dalam penelitian ini ialah data sekunder dengan menggunakan laporan keuangan berbentuk triwulan sebagai data yang diterbitkan oleh situs OJK serta situs resmi oleh bank yang dijadikan sampel penelitian. Metode pengambilan sampel menggunakan purposive sampling. Populasi penelitian menggunakan 11 BUS dengan periode 2015-2018. Populasi penelitian berupa Bank Umum Syariah (BUS) yang berjuamlah 14 buah sampai dengan tahun 2018 tetapi sampel penelitian hanya 11 BUS dikarenakan keterbatasan data. kriteria untuk pemilihan sampel dalam penelitian ini dapat dilihat pada tabel 3. Penelitian ini menguji apakah risiko operasional sebagai variabel dependen terhadap variabel independen dari pendapatan bank umum syariah diantaranya yakni murabahah, ijarah, mudharabah, dan musyarakah berpengaruh signifikan seperti hipotesis yang telah ditentukan sebagai berikut:

$\mathrm{H}_{1}$ : Pendapatan murabahah berpengaruh positif terhadap risiko operasional

$\mathrm{H}_{2}$ : Pendapatan ijarah berpengaruh negatif signifikan terhadap risiko operasional

$\mathrm{H}_{3}$ : Pendapatan mudharabah berpengaruh positif terhadap risiko operasional

H4: Pendapatan musyarakah berpengaruh positif signifikan terhadap risiko operasional

$\mathrm{H}_{5}$ : Pendapatan fee berpengaruh tidak signifikan terhadap risiko operasional

Analisis data dalam penelitian ini menggunakan analisis regresi data panel. Data panel adalah pengelompokan data runtut waktu (time series) dan data silang (cross section). Time Series adalah suatu metode intrinsik yang biasa digunakan. Time series bermaksud untuk mengamati suatu variabel dalam bentuk interval waktu diskrit. Waktunya terdiri dari tahun sebelumnya sampai tahun ini. Dengan mempelajari modifikasi permintaan terhadap waktu maka keterkaitan antara permintaan dan waktu dapat diformulasikan dan kemudian digunakan untuk memprediksi permintaan di periode selanjutnya, dan cross section adalah sebuah data pada suatu kurun waktu yang terdiri dari beberapa objek.

Tabel 3. Kriteria Pemilihan Sampel Bank Umum Syariah (BUS)

\begin{tabular}{clcc}
\hline No. & \multicolumn{1}{c}{ Ketentuan } & Total Bank & Total Data \\
\hline 1. & $\begin{array}{l}\text { BUS yang terdaftar pada OJKdalam } \\
\text { kurun waktu 4 tahun dari2015-2018. }\end{array}$ & 14 & 224 \\
\hline 2. & $\begin{array}{l}\text { BUS yang mempublikasikanlaporan tri } \\
\text { wulan dari tahun 2015-2018 }\end{array}$ & 11 & 176 \\
\hline & $\begin{array}{l}\text { Laporan keuangan yang } \\
\text { diterbitkanmemuat berbagai variabel } \\
\text { yangakan digunakan dalam } \\
\text { penelitianperiode 2015-2018. }\end{array}$ & 11 & 176 \\
\hline Jumlah sampel & 11 & 176 \\
\hline
\end{tabular}

Sumber: Data diolah (2019)

\section{Hasil dan Pembahasan}

\section{Analisis Statistik Deskriptif}

Deskriptif merupakan penyajian gambaran berkaitan dengan variabel penelitian yang digunakan. Variabel-variabel yang digunakan dalam penelitian ini yaitu Risiko Operasional 
(RO), Murabahah (MRB), Ijarah (IJH), Mudharabah (MDR), Musyarakah (MSY), Fee yang terdiri dari 11 bank umum syariah dalam 4 tahun dari tahun 2015 hingga tahun 2018. Adapun deskripsi data setiap variabel dari hasil olah data menggunakan alat statistik berupa eviews yaitu sebagai berikut:

Tabel 4. Statistik Deskriptif

\begin{tabular}{ccccccc}
\hline & RO & MRB & IJH & MDR & MSY & FEE \\
\hline Mean & 1025940 & 746761.1 & 23116.20 & 50867.75 & 252981.4 & 165792 \\
\hline Max & 7524166 & 4483277 & 267087.0 & 367275.0 & 1963692 & 1108344 \\
\hline Min & 121.7160 & 2469.000 & 0.000000 & 0.000000 & 1027.000 & 415.000 \\
\hline Std. Dev & 1411608 & 895986.8 & 50513.35 & 75768.31 & 382148.4 & 2097107 \\
\hline Observ & 167 & 167 & 167 & 167 & 167 & 167 \\
\hline
\end{tabular}

Sumber: Data diolah (2019)

Hasil analisis regresi statistic deskriptif pada tabel 3, tingkat rata-rata (mean) risiko operasional sebagai variabel dependen dalam penelitian sebesar 1025940 menunjukkan bahwa total aset menurut risiko bank umum syariah menghasilkan $10.25 \%$ yang berarti kecukupan modal bank umum syariah diatas standar Peraturan BI No.15/12/PBI/2014 tentang kewajiban penyediaan modal minimum bank umum, dimana PBI mensyaratkan bahwa bank wajib untuk memenuhi rasio kewajiban modal minimum sebesar $8 \%$ dan dikategorikan baik. Nilai RO sebesar 121.7160 dan dengan standar deviasi 1411608, yang menandakan lebih tinggi dari pada mean $(1411608>1025940)$, hal ini berarti simpangan data pada tingkat risiko operasional cukup baik dikarenakan perbedaan rata-rata risiko operasional dengan standar deviasi tidak jauh berbeda.

Penelitian ini menggunakan tingkat pendapatan sebagai variabel independen/bebas yang menggambarkan kondisi pendapatan bank umum syariah di Indonesia selama dari tahun 2015-2018. Tingkat pendapatan rata-rata variabel independen ( ) yaitu murabahah senilai 746761.1 selama kurun waktu 4 tahun yang menandakan bahwa transaksi murabahah cukup banyak diminati dalam hal jual beli. Tingkat pendapatan murabahah tertinggi senilai 4483277 sedangkan tingkat terendah pendapatan murabahah senilai 2469.000 dengan nilai standar deviasi sebesar 895986.8 yang menandakan lebih rendah dari pada mean (895986.8 $>746761.1)$.

Tingkat pendapatan rata-rata variabel independen ( ) yaitu ijarah senilai 23116.20 selama kurun waktu 4 tahun yang menandakan bahwa transaksi ijarah cukup banyak diminati dalam hal sewa-menyewa. Tingkat pendapatan ijarah tertinggi senilai 267087.0 sedangkan tingkat terendah pendapatan ijarah senilai 0.000000 dengan nilai standar deviasi sebesar 50513.35 yang menandakan lebih tinggi dari pada mean $(50513.35>23116.20)$. Tingkat pendapatan rata-rata variabel independen ( ) yaitu mudharabah senilai 50867.75 selama kurun waktu 4 tahun yang menandakan bahwa transaksi mudharabah cukup banyak diminati dalam hal usaha bagi hasil. Tingkat pendapatan mudharabah tertinggi senilai 367275.0 sedangkan tingkat terendah pendapatan mudharabah senilai 0.000000 dengan nilai standar deviasi sebesar 75768.31 yang menandakan lebih tinggi dari pada mean (75768.31 $>50867.75$. Tingkat pendapatan rata-rata variabel independen (x4) yaitu musyarakah senilai 252981.4 selama kurun waktu 4 tahun yang menandakan bahwa transaksi musyarakah cukup banyak diminati dalam hal usaha bagi hasil. Tingkat pendapatan musyarakah tertinggi senilai 19636692 sedangkan tingkat terendah pendapatan musyarakah senilai 1027.000 
dengan nilai standar deviasi sebesar 382148.4 yang menandakan lebih tinggi dari pada mean (382148.4 > 252981.4). Tingkat pendapatan rata-rata variabel independen ( ) yaitu fee senilai 165792.0 selama kurun waktu 4 tahun yang menandakan bahwa transaksi fee cukup banyak diminati dalam hal usaha bagi hasil. Tingkat pendapatan fee tertinggi senilai 1108344 sedangkan tingkat terendah pendapatan fee senilai 415.0000 dengan nilai standar deviasi sebesar 209710.7 yang menandakan lebih tinggi dari pada mean (209710.7 > 165792)

Kesimpulan yang dapat diambil dilihat dari tabel 4.2 di atas bahwa tingkat pendapatan tertinggi pereode 2015-2018 dari hasil regresi data panel sebesar 4483277 berada di variabel independen yaitu murabahah. Murabahah adalah variabel yang paling banyak menghimpun pendapatan selama 4 tahun ini dari 11 bank umum syariah, sedangkan untuk pendapatan terendah berada di variabel yaitu fee sebesar 415.000. Hasil perhitungan deskriptif statistik yang dilakukan, nilai mean sebesar 1025940, deviasi standar sebesar 1411608, skewness sebesar 2.124938 dan median sebesar 394571.0 yang menunjukkan bahwa nilai-nilai tersebut lebih dari nol. Dengan demikian risiko operasional tidak termasuk dalam kategori distribusi normal.

\section{Estimasi Regresi Data Panel}

\section{a. Common Effect Model}

Estimasi regresi data panel Common Effect Modeldengan metode OrdinaryLeast Square yaitu sebagai berikut:

Tabel 5. Hasil Estimasi Common Effect Model

\begin{tabular}{crccc}
\hline Variabel & Coefficient & Std.Error & t-Statistic & Prob. \\
\hline MRB & 1.346848 & 0.093382 & 14.42294 & 0.0000 \\
\hline IJR & 0.310116 & 1.125058 & 0.842805 & 0.7832 \\
\hline MDR & -0892635 & 0.867237 & -1.029286 & 0.3048 \\
\hline MSY & 0.842805 & 0.113055 & 7.454831 & 0.0000 \\
\hline FEE & -0007454 & 0.005788 & -1.287846 & 0.1995 \\
\hline C & 59422.35 & 33615.39 & 1.767718 & 0.0789 \\
\hline
\end{tabular}

R-Square $=0.935972$

Dari tabel diatas, estimasi regresi data panel dengan Common EffectModel (CEM) menghasilkan $R^{2}$ sebesar 0,935972 yang berartiMurabahah, Ijarah, Mudharabah, Musyarakah, dan Fee secara bersamaan mempengaruhi risiko operasional sebesar 93\%. Dilihat dari probabilitas model CEM dapat dilihat variabel Ijarah, Mudharabah, Musyarakah $<0.05$ yang berarti berpengaruh terhadap risiko operasional. Sedangkan murabahah tidak berpengaruh terhadap variabel terikat yaitu risiko operasional karena nilai prob $>0.05$.

\section{b. Fixed Effect Model}

Estimasi regresi data panel Fixed Effect Model dengan metode OrdinaryLeast Square yaitu sebagai berikut: 
Tabel 6. Estimasi Fixed Effect Model

\begin{tabular}{crccc}
\hline Variabel & Coefficient & Std.Error & t-Statistic & Prob. \\
\hline MRB & 1.152403 & 0.113615 & 10.14309 & 0.0000 \\
\hline IJR & 1.548635 & 1.106631 & 1.399414 & 0.1636 \\
\hline MDR & 0.158005 & 0.985488 & 0.160331 & 0.8728 \\
\hline MSY & 0.601493 & 0.181859 & 3.307462 & 0.0012 \\
\hline FEE & -0.011779 & 0.005555 & -2.120339 & 0.0355 \\
\hline C & 156033.9 & 41720.08 & 3.740020 & 0.0003 \\
\hline
\end{tabular}

R-Squared $=0.948220$

Dari tabel diatas, hasil estimasi fixed effect model $\mathrm{R}^{2}=0.948220$ yang berarti variabel bebas Murabahah, Ijarah, Mudharabah, Musyarakah, dan Fee secara bersamaan mempengaruhi variabel terikat yaitu risiko operasional sebesar 94,8\%. Kemudian dilihat Dilihat dari nilai probabilitas diatas didapati bahwa variabel Murabahah, Musyarakah danfee $<0.05$ yang berarti berpengaruh terhadap risiko operasional. Sedangkan ijarah dan mudharabah tidak berpengaruh terhadap variabel terikat yaitu risiko operasional karena nilai prob $>0.05$.

\section{c. Random Effect Model}

Hasil estimasi dari random effect model dengan metode GeneralizedLeast Square (GLS) diperoleh sebagai berikut:

Tabel 7. Estimasi Random Effect Model

\begin{tabular}{ccccc}
\hline Variabel & coefficient & Std.Error & t-Statistic & Prob. \\
\hline MRB & 1.288180 & 0.093352 & 13.79921 & 0.0000 \\
\hline IJR & 0.775891 & 1.064693 & 0.728746 & 0.4672 \\
\hline MDR & -0.606315 & 0.862521 & -0.702956 & 0.4830 \\
\hline MSY & 0.809427 & 0.119684 & 6.763034 & 0.0000 \\
\hline FEE & -0.008225 & 0.005399 & -1.523526 & 0.1295 \\
\hline C & 77882.51 & 39337.03 & 1.979878 & 0.0493
\end{tabular}

$$
\text { R-Squared }=0.914323
$$

Hasil estimasi regresi data panel melalui pendekatan Random EffectModel (REM) diketahui $\mathrm{R}^{2}$ $=0.914323$ yang Murabahah, Ijarah, Mudharabah, Musyarakah berarti variabel bebas, dan Fee secara besama-sama mempengaruhi variabel terikat yaitu risiko operasional sebesar $9.14 \%$.

\section{Pemilihan Model Terbaik}

\section{a. Uji Chow}

Uji chow digunakan untuk memilih antara Common Effect Model dengan Fixed Effect Model, dengan hipotesis sebagai berikut: 
Tabel 8. Uji Chow

\begin{tabular}{ccc}
\hline Statistik & Df & N.Sig \\
\hline 3.784702 & $(10.160)$ & 0.0001
\end{tabular}

Hasil estimasi antara Common Effect Model dan Fixed Effect Model pada tabel 6 didapati nilai Probabilitas $0.001<$ (lebih kecil) dari taraf signifikansi 5\% yang berarti ditolak, dan model yang terbaik untuk digunakan yaitu Fixed Effect Model.

\section{b. Uji Hausman}

Uji Hausman digunakan untuk memilih estimasi antara Random EffectModel dengan Fixed Effect Model yang diperoleh F-statistik denganhipotesis sebagai berikut:

Tabel 9. Uji Hausman

\begin{tabular}{ccc}
\hline Statistik & Df & N.Sig \\
\hline 21.035361 & 5 & 0.0008
\end{tabular}

Hasil estimasi uji Hausman diperoleh nilai Probabilitas $0.008<$ taraf signifikansi $5 \%$ yang artinya ditolak, sehingga model sebesar regresi data panel yang terbaik antara Random Effect Model dan FixedEffect Model yaitu Fixed Effect Model.

\section{Pengujian Hipotesis}

\section{a. Uji F (Simultan)}

Tabel 10. Uji F

\begin{tabular}{cc}
\hline F-Statistik & N.Sig \\
\hline 195.3349 & 0.000000
\end{tabular}

Berdasarkan hasil regresi diperoleh nilai F-statistik sebesar 195.3349 dengan probabilitas 0.000000. Apabila dilihat dengan taraf signifikansi 5\% maka probabilitas F statistik lebih kecil dari pada taraf signifikansi yang berarti variabel independen murabahah, ijarah, mudharabah, musyarakah, dan fee secara bersama-sama berpengaruh terhadap variabel dependen yaitu risiko operasional di 11 bank umum syariah selama periode 2015-2018.

\section{b. Koefisien Determinasi $\left(\boldsymbol{R}^{2}\right)$}

Tabel 11. R-Square

Nilai R-Square $\quad 0.948220$

Nilai koefisien terletak antara 0 dan 1 semakin garis regresi mendekati 1 maka akan semakin baik dalam menjelaskan data aktualnya. Nilai $R^{2}$ pada hasil regresi penelitian ini sebesar 0.948220 sehingga variabel dependen dapat dijelaskan sebesar $94 \%$ oleh variabel independen dalam penelitian ini.

\section{c. Uji T (Parsial)}

Uji t merupakan pengujian regresi secara parsial untuk mengetahui pengaruh variabel indepnden secara individu mampu mempengaruhi variabel dependen.Variabel independen dikatakan berpengaruh signifikan jika nilai probabilitasnya lebih kecil dari pada taraf signifikansi 5\%. Adapun hasil regresi yaitu sebagai berikut:

1) Koefisien variabel murabahah diketahui sebesar 1.152403 dengan tingkat probabilitas 0.0000 menunjukkan lebih kecil dari taraf signifikansi yang menyatakan bahwa variabel 
independen murabahah berpengaruh terhadap risiko operasional pada bank umum syariah.

2) Koefisien variabel ijarah diketahui sebesar 1.548635 dengan tingkat probabilitas 0.1636 menunjukkan lebih besar dari taraf signifikansi yang menyatakan bahwa variabel independen ijarah tidak berpengaruh terhadap risiko operasional pada bank umum syariah.

3) Koefisien variabel mudharabah diketahui sebesar 0.158005 dengan tingkat probabilitas 0.8728 menunjukkan lebih kecil dari taraf signifikansi yang menyatakan bahwa variabel independen mudharabah tidak berpengaruh terhadap risiko operasional pada bank umum syariah.

4) Koefisien variabel musyarakah diketahui sebesar 0.601493 dengan tingkat probabilitas 0.0012 berarti bila dibandingkan dengan nilai taraf signifikansi maka lebih kecil. Hal ini menunjukan bahwa variabel independen atau prediktor pendapatan musyarakah mempengaruhi risiko operasional bank umum syariah.

5) Koefisien variabel fee diketahui sebesar -0.011779 dengan tingkat probabilitas 0.0355 yang berarti bila dibandingkan dengan nilai taraf signifikansi maka lebih kecil. Hal menunjukkan bahwa variabel independen (prediktor) pendapatan fee mempengaruhi risiko operasional bank umum syariah.

\section{d. Uji Asumsi Klasik}

Berdasarkan hasil pemilihan model dalam penelitian ini menggunakan model fixed effect untuk memecahkan masalah penelitian. Model fixed effect dilakukan dengan menggunkan pendekatan Least Square Dummy Variable (LSDV). Dikarenakan hasil pemilihan modelnya adalah baik atau fixed effect oleh karenanya dilakukan uji asumsi klasik agar dapat ditahui model yang terpilih apakah memenuhi disyaratkan BLUE (Best Linier Unbias Estimator).

\section{e. Uji Normalitas}

Uji signifikansi pengaruh variabel independen terhadap variabel dependen melalui uji $t$ hanya akan valid apabila residual yang didapatkan berdistribusi normal. Pada penelitian ini uji normalitas dilakukan dengan uji Jarque-Bera. Hipotesis dari penelitian ini yaitu:

$\mathrm{H}_{0}$ : Residual tidak berdistribusi normal

$\mathrm{H}_{1}$ : Residual berdistribusi normal

Tabel 12. Uji Normalitas

\begin{tabular}{rccl}
\hline N. Sig & JB & Skewness & Kurtosis \\
\hline 0.000000 & 303.9355 & 0.643348 & 9.482574
\end{tabular}

Terlihat pada tabel 4.11 dari hasil uji normalitas menunjukkan bahwa nilai probabilitas sebesar $0.000000>$ taraf signifikansi 5\% yang artinya ditolak. Apabila ditolak ini menandakan jika model fixedeffect berdistribusi normal.

\section{f. Uji Multikolinearitas}

Uji multikolinearitas ini untuk menunjukkan tingkat hubungan variabel-variabel prediktor secara linear dalam regresi linear berganda. Model regresi yang diperoleh dinyatakan baik bias diamati pada variabel prediktor atau variabel bebas satu sama lain maupun tidak terjadi korelasi. 
Tabel 13. Uji Multikolinearitas

\begin{tabular}{ccccccc}
\hline & RO & MRB & IJH & MDR & MSY & FEE \\
\hline RO & 1.000000 & 0.837690 & 0.758877 & 0.867845 & 0.764425 & 0.708351 \\
\hline MRB & 0.837690 & 1.000000 & 0.749573 & 0.823735 & 0.598785 & 0.640036 \\
\hline IJH & 0.758877 & 0.749573 & 1.000000 & 0.787486 & 0.377133 & 0.557112 \\
\hline MDR & 0.867845 & 0.823735 & 0.787486 & 1.000000 & 0.663225 & 0.610435 \\
\hline MSY & 0.764425 & 0.598785 & 0.377133 & 0.663225 & 1.000000 & 0.518535 \\
\hline FEE & 0.708351 & 0.640036 & 0.557112 & 0.610435 & 0.518535 & 1.000000 \\
\hline
\end{tabular}

Terlihat bahwa dari hasil perhitungan uji multikolinearitas, korelasi dari semua variabel independen $>0.85$ yang artinya diterima atau tidaknya multikolinearitas pada variabel independen.

\section{Pembahasan}

\section{a. Pengaruh Pendapatan Murabahah Terhadap Risiko Operasional}

Terlihat dari hasil regresi secara parsial murabahah berpengaruh terhadap risiko operasional karena nilai Probabilitas murabahab 0.000 kurang dari taraf signifikansi 5\%. Sehingga dapat ketahui bahwa variabel bebas (murabahah) dari tahun 2015 hingga 2018 berpengaruh terhadap risiko operasional yang dihitung menggunakan metode Basiclndocator Approach (BIA). Berpengaruhnya murababah terhadap risikooperasional menurut Samsudin et. al (2003) dapat dikarenakan atas dua hal yaitu untuk transaksi murabahah dengan pesanan bersifat mengikat risikonya bank syariah mendekati risiko seperti yang dihadapi bank konvensional. Sedangkan untuk ransaksi murabahah tanpa pesanan atau dengan pesanan sifatnya tidak mengikat, sehingga nasabah tidak harus membeli barang tersebut hal ini menimbulkan bank akan menerima 2 risiko yang pertama, tidak ada jaminan bagi bank syariah seandainya pembeli membatalkan transaksi. Kedua bank risiko kerugian yang diakibatkan karena menurunnya nilai barang akibat cacat atau rusak selama masa penyimpanan.

\section{b. Pendapatan Ijarah Terhadap Risiko Operasional}

Terlihat dari hasil regresi data panel secara parsial menyatakan ijarah tidak berpengaruh terhadap risiko operasional karena nilai probabilitas ijarah 0.1636 lebih besar dari taraf signifikansi 5\% tetapi pendapatanijarah belum mencapai standar kecukupan modal sebesar 8\%. Sehingga dapat ketahui bahwa variabel bebas ijarah dari tahun 2015 hingga 2018 tidak berpengaruh terhadap risiko operasional dengan perhitungan metode BIA. Tidak berpengaruhnya pendapatan ijarah terbadap risiko operasional dikarenakan ketika berlangsungnya transaksi oleh bank syariah dalam membeli aktiva nasabah aktiva tersebut baik-baik saja tidak buruk atau jelek. Dari pernyataan ini bank syariah mesti benar-benar menjaga agar terhindar dari risiko ini, karena dapat mengurangi kepercayaan nasabah yang mengakibatkan pembatalan kontrak ditengah periode, risiko yang kedua yaitu bank syariah kurang teliti dalam melakukan pemeriksaan karena aktiva dalam sengketa sehingga terjadi penipuan dan kecolongan, risiko yang ketiga yaitu barang tersebut rusak pada saat dalam penguasaan bank syariah yang bisa disebabkan karena besi/alumunium, salah dalam pemakaian, karena kesengajaan oknum tertentu, bisa juga karena kebakaran, maupun kebangkrutan sehingga dalam hal ini bank syariah yang menanggung biaya pemeliharaan aset. 
Hasil penelitian ini sama dengan penelitian yang dihasilkan oleh Fitriana Dwi Prasetyowati dan Moh. Khoiruddin ${ }^{17}$ dalam penelitiannya yang berjudul pengaruh struktur kepemilikan yaitu proksi highest dan block struktur pendapatan yaitu proksi profit loss sharing income (PLS) dan non profit sharing income (NonPLS), struktur deposito yaitu profit sharing investment account (PSIA) dan non profit loss sharing investmen account (Non PSIA) terhadap insolvency risk. Terlihat dari hasil penelitianbahwa highest berpengaruh positif signifikan pada nsolvency risk, sedangkan block, PLS income, nonPLS income, PSIA dan non PSIA berpengaruh negative signifikan terhadap insolvency risk pada bank syariah di Indonesia.

\section{c. Pengaruh Pendapatan Mudharabah Terhadap Risiko Operasional}

Hasil regresi data panel yang menunjukkan secara parsial murabahabtidak berpengaruh terhadap risiko operasional karena nilaiProbabilitasmudharabah 0.8728 lebih besar dari taraf signifikansi $5 \%$, dan pendapatan mudharabah mencapai standar kecukupan modal sebesar 8\%. Sehingga dapat ketahui bahwa variabel bebas (mudharabah) dari tahun 2015 hingga 2018 tidak berpengaruh terhadap risiko operasional dengan perhitungan metode BIA. Tidak berpengaruhnya pendapatan mudharabah terhadap risiko operasional dikarenakan proseduroperasional pada transaksi mudharabah terhadap barang yang telah dipesan terbeli oleh nasabah itu sendiri.

Terlihat dari hasil regresi menunjukkan perbedaan dengan hasil penelitian dari Ousmane Diallo, dkk. ${ }^{18}$ dalam penelitiannya analisis yang mempengaruhi likuiditas, kredit, dan risiko operasional pada keunagn bank syariah di Indonesia tahun 2007 hingga 2013. Hasil penelitian menunjukkan bahwa sistem perbankan syariah di Indonesia dapat dinyatakan memiliki produk perbankan berbasis"pembagian risiko".dimana terdapat korelasi antara risiko operasional dan pembiayaan mudharabah.

\section{d. Pengaruh Pendapatan Musyarakah Terhadap Risiko Operasional}

Hasil regresi data panel menunjukkan secara parsial musyarakab berpengaruh terhadap risiko operasional karena nilai probabilitasmusyarakah 0.0012 lebih kecil dari taraf signifikansi 5\%. Sehingga dapat ketahui bahwa variabel bebas musyarakah dari tahun2015 hingga 2018 berpengaruh terhadap risiko operasional yang dihitung menggunakan metode Basic Indocator Approach (BIA).

Berpengaruhnya pendapatan musyarakah terhadap risiko operasional disebabkan karena bank syariah kurang tepat dalam menentukan keuangan perusahaan sehingga dalam pengelolaan proyek yang sedang berlangsung oleh karena itu pihak bank harus menerima informasi keuangan yang memadai dan tepat waktu agar bank syariah dapat mengukur kemungkinan untuk memperbaiki manajemen pada waktu yang tepat.

Terlihat dari hasil penelitian ini ternyata sama dengan penelitian yang dilkukan Ousmane Diallo, dkk. ${ }^{19}$ dalam penelitiannya yang berjudul Analysis of The Influence of Liquidity, Credit and Operational Risk, inIndonesian Islamic Bank's Financing for The Period 2007-2013. Hasilpenelitiannya menunjukkan bahwa sistem perbankan syariah di Indonesia dapat

\footnotetext{
${ }^{17}$ Fitriana Dwi Prasetyowati and Moh Khoiruddin, "Pengaruh Struktur Kepemilikan, Struktur Pendapatan, Struktur Deposito Terhadap Insolvency Risk Bank Syariah,” Management Analysis Journal 6, no. 2 (2017): 233245.

18 Ousmane Diallo, Tettet Fitrijanti, and Nanny Dewi Tanzil, "Analysis of the Influence of Liquidity, Credit and Operational Risk, in Indonesian Islamic Bank's Financing for the Period 2007-2013," Gadjah Mada International Journal of Business 17, no. 3 (2015): 279-294.

${ }^{19}$ Diallo, Fitrijanti, and Tanzil.
} 
dinyatakan memiliki produk perbankan berbasis "pembagian risiko". Risiko kredit, risiko operasional dan likuiditas secara keseluruhan memiliki pengaruh yang signifikan terhadap pembiayaan mudharabah, musyarakah, murabahah,istishna ijarah, dan qardh. Tetapi tidak ada hubungan antara risiko operasional dan pembiayaan musyarakah.

\section{e. Pengaruh Pendapatan Fee Terhadap Risiko Operasional}

Hasil regresi data panel yang menunjukkan secara parsial Fee berpengaruh terhadap risiko operasional karena nilai probabilitas murabahah 0.0355 lebih sedikit dibandingkan taraf signifikansi 5\%. Sehingga dapat ketahui bahwa variabel bebas (Fee) dari tahun 2014 hingga 2018 berpengaruh terhadap risiko yang dihitung menggunakan metode Basic Indicator Approach (BIA). Berpengaruhnya pendapatan fee pada risiko operasional dikarenakan pertama kurangnya manajemen teknologi informasi dan buman error atau fraud.

Hasil penelitian ini sesuai dengan penelitian yang dari Sianipar dan Natalie et.al yang berjudul Commission and Fee. Hasil dari penelitiannya yaitu commission and fee berpengaruh negatif tidak signifikan terhadap risiko. Pendapatan ini memiliki risiko yang berbeda dengan pendapatan-pendapatan bank syariah lainnya dikarenakan pencatatan atau pengakuan yang dilakukannya terjadi pada saat saat transaksi diterima.Sehingga dapat disimpulkan bahwa risiko pendapatan commission and fee jauh lebih kecil dari pada pendapatan lainnya. Selainitu commission and fee juga bukan merupakan pembiayaan bank maka dari itu semakin besar pendapatan commission and fee maka semakin rendah risikonya dan apabila pendapatan commission and fee besar akan membantu risiko pembiayaan menjadi rendah. Sehingga dapat dikatakan bahwa pendapatan commission and fee (COM) berpengaruh tidak signifikan terhadap risiko.

\section{Kesimpulan}

Risiko operasional sebagai risiko akibat ketidakcukupan dan/atau tidak berfungsinya proses internal, kesalahan manusia, kegagalan sistem, dan/atau adanya kejadian-kejadian eksternal yang mempengaruhi operasional bank. Setelah dilakukan penelitian tentang pengaruh pendapatan bank terhadap risiko operasional dengan sampel bank umum syariah sebanyak 11 didapat kesimpulan bahwa variabel independen yang berpengaruh terhadap risiko operasional yaitu murababah, musyarakah, dan fee sedangkan ijarah dan mudharabah tidak berpengaruh terhadap risiko operasional pada bank umumsyariah.

Pada penelitian ini menggunakan pendekatan indikator dasar dalam menghitung risiko operasional pada perbankan syariah. Sehingga diharapkan untuk peneliti selanjutnya menggunakan metode pengukuran risiko operasional Standardized Approach maupun Advance Measure Approach (AMA).

\section{Daftar Pustaka}

Abedifar, Pejman, Philip Molyneux, and Amine Tarazi. "Non-Interest Income and Bank Lending." Journal of Banking \& Finance 87 (2018): 411-426.

Asnaini, Sri Wahyuni. "Faktor-Faktor Yang Mempengaruhi Non Performing Financing (NPF) Pada Bank Umum Syariah Di Indonesia.” Jurnal Tekun 5, no. 02 (2014): 264284.

Awan, Hayat M., and Khuram Shahzad Bukhari. "Customer's Criteria for Selecting an Islamic Bank: Evidence from Pakistan.” Journal of Islamic Marketing, 2011. 
Capriani, Ni Wayan Wita, and I. Made Dana. "Pengaruh Risiko Kredit Risiko Operasional Dan Risiko Likuiditas Terhadap Profitabilitas BPR Di Kota Denpasar.” E-Jurnal Manajemen Universitas Udayana 5, no. 3 (2016).

Chi Xu, et al. "Double Correlation Model For Operational Risk : Evidence From Chinese Commercial Bank. Preprint Submited to Physica A (University of Science and Technology)", PII. SO 378-4371 (18) 31369-4, 10 Oktober 2018.

Diallo, Ousmane, Tettet Fitrijanti, and Nanny Dewi Tanzil. "Analysis of the Influence of Liquidity, Credit and Operational Risk, in Indonesian Islamic Bank's Financing for the Period 2007-2013." Gadjah Mada International Journal of Business 17, no. 3 (2015): 279-294.

Fichez, R., L. Breau, Christine Chevillon, Sandrine Chifflet, P. Douillet, V. Faure, J.-M. Fernandez, P. Gérard, L. Hédouin, and A. Lapetite. "Origine, Transport et Devenir Des Apports Naturels et Anthropiques Dans Le Lagon Sud-Ouest de NouvelleCalédonie." Journal de La Société Des Océanistes, no. 126-127 (2008): 41-58.

Hidayat, Muhammad Rifqi, dan Parman Komarudin. "Penanganan Non-Performing Finance dalam Akad Musyarakah di Bank Kalsel Syariah." At-Taradhi: Jurnal Studi Ekonomi 9, no. 1 (2018): 1-9.

Karim, Adiwarman. Bank Islam Analisis Fiqh dan Kenangan. Jakarta : PT. Raja Grafindo Persada, 2004.

Margaretha, Farah, and Diana Setiyaningrum. "Pengaruh Resiko, Kualitas Manajemen, Ukuran Dan Likuiditas Bank Terhadap Capital Adequacy Ratio Bank-Bank Yang Terdaftar Di Bursa Efek Indonesia.” Jurnal Akuntansi Dan Keuangan 13, no. 1 (2011): 47-56.

Prasetyo, Dwi Agung dan Ni Putu Ayu Darmayanti. "Pengaruh Risiko Kredit, Likuiditas, Kecukupan Modal, dan Efisiensi Operasional Terhadap Profitabilitas Pada PT BPD Bali”, E-Jurnal Manajemen Unud, Vol. 4, No. 9, 2015.

Prasetyowati, Fitriana Dwi, and Moh Khoiruddin. "Pengaruh Struktur Kepemilikan, Struktur Pendapatan, Struktur Deposito Terhadap Insolvency Risk Bank Syariah.” Management Analysis Journal 6, no. 2 (2017): 233-245.

Santos, Rachel Barbosa dan Ualison Rebula de Oliveira. "Analysis of Occupational Risk Management Tools for the Film and Television Industry (Fluminense Federal University)", International Journal ofIndustrial Ergonomics, 2019.

Sjahdeini, Sutan Remy. Perbankan Islam dan kedudukannya dalam tata bukum perbankan Indonesia. Jakarta: Pustaka Utama Grafiti, 2005.

Sparta. "Analisis Pengaruh Efisiensi dan Kecukupan Modal Terhadap Kinerja Keuangan pada Bank Pembangunan Daerah Di Indonesia", JurnalEkonomi dan Bisnis, Vol. 20, No. 1, 2017.

Williams-Young, David, Franco Egidi, and Xiaosong Li. "Relativistic Two-Component Particle-Particle Tamm-Dancoff Approximation." Journal of Chemical Theory and Computation 12, no. 11 (2016): 5379-5384.

Yulianti, Rahmani Timorita. "Manajemen Risiko Perbankan Syari'ah." Jurnal Fakultas Hukum UII 3, no. 2 (2009): 151-165. 
Yunita, Nurul, and Muhamad Syaichu. "Analisis Pengaruh Bank Income Structure Terhadap Risiko Bank Syariah Di Indonesia (Studi Kasus Pada Bank Umum Syariah Yang Terdaftar Di Bursa Efef Indonesia Periode 2011-2015).” Diponegoro Journal of Management 6, no. 4 (2017): 714-728. 